\title{
Proximate composition, minerals profile, and predominant sugars by ion chromatograph along the physiological development of jabuticaba var. Pingo de mel
}

\author{
Lismaíra Gonçalves Caixeta GARCIA ${ }^{1}$, Flávio Alves da SILVA ${ }^{2 *}$, \\ Eduardo Ramirez ASQUIERI ${ }^{3}$, Eduardo Valério de Barros VILAS BOAS ${ }^{4}$, Felipe Iwagaki Braga OGANDO 5 , \\ Claudio Lima de AGUIAR ${ }^{5}$, Clarissa DAMIANI ${ }^{6}$
}

\begin{abstract}
The objective of this study was to characterize jabuticaba fruits for their proximate composition, minerals profile, and predominant sugars during fruit physiological development. The fruits were harvested ten days after anthesis (DAA) until maturity, at intervals of four days between collections. The period between anthesis and maturity was 34 days. An increase in moisture was observed, as for protein and lipids up to $18 \mathrm{DAA}$, with subsequent reduction until ripening, while an opposite behavior was observed for ash and carbohydrates levels. In general, minerals decreased throughout the fruit development. Regarding the carbohydrates profile, fructose showed the highest concentration, followed by glucose and sucrose, respectively, with an increase during ripening for all sugars. Whereas the sweet taste of fruit is a major factor for both consumption in natura and processing, we observed that jabuticaba fruits harvested 34 days after anthesis presented the best results.
\end{abstract}

Keywords: anthesis; fructose; glucose; Myrciaria sp.

Pratical Application: Studying the physiological development of jabuticaba fruits to determine the optimum harvest point.

\section{Introduction}

Fruits are one of the fastest growing agricultural markets in Brazilian agriculture, and jabuticaba tree (Myrciaria sp) stands out among the native species. Jabuticaba fruits are presented in the form of globular berry, smooth skin, with up to $3 \mathrm{~cm}$ in diameter, bright green to dark violet depending on the ripening stage, whitish pulp, mucilaginous, bitter-sweet, tasty, often containing one small seed, but may be up to four (Donadio, 2000; Boari Lima et al., 2008). The sweet taste and acidity of jabuticaba fruit is due to sugars, organic acids, and terpenes in its composition (Plagemann et al., 2012).

Among the existing varieties, the Pingo de Mel variety stands out, being widely cultivated in the region of Goiás, with fruit production once a year, for three months. However, it is a very perishable fruit, with shelf life of up to three days after harvesting, which hinders its commercialization in natura.

Knowledge about the development pattern of a fruit from flowering allows determining the maturity indices, especially regarding the optimum maturity stage for the commercial harvest, and is essential to determine agricultural practices (Coombe, 1976). When the pattern of growth and development of fruit is well known, agricultural practices such as irrigation, application of phytorregulators and pesticides, and bagging of fruits can be carried out effectively at the right time. However, few studies are found in literature about the behavior of the different maturity stages.

Assessing the proximate composition of foods is very important, since it shows the nutritional value and the proportion of components in $100 \mathrm{~g}$ of product (edible portion). Given the above, the objective of this study was to characterize the jabuticaba fruits var. Pingo de Mel for proximate composition, mineral profile, and free sugars by ion chromatograph over the physiological development.

\section{Materials and methods}

The experiment was performed from September to October 2014, at the Fazenda \& Vinícula Jabuticabal in New Fatima, district of Hidrolândia-GO ( $16^{\circ} 55^{\prime} 32.35^{\prime \prime}$ S, and $49^{\circ} 21^{\prime} 39.76^{\prime \prime}$ W), $35.6 \mathrm{~km}$ from Goiânia-GO. Seventy trees were selected at random, homogenous as to the size and age, and branches were marked at 
the time of anthesis, with different colored wool yarn. The first harvest occurred at ten days after the anthesis, at intervals of four days until 34 DAA (days after the anthesis), when the fruits reached maturity, characterized by the black-violet color of the bark and the beginning of fruit fall, totaling 7 collection points. About $300 \mathrm{~g}$ of the jabuticaba fruits var. Pingo de mel were collected in the morning at random, among the 70 previously selected trees, and transported to the laboratory. Samples were collected 10, 14, 18, 22, 26, 30 and 34 DAA, being collected $300 \mathrm{~g}$ of the fruit each stage of development. Fruits were selected for the presence of defects or pests, and washed in tap water to remove surface dirt. In the days of harvest the fruits were frozen at $-18{ }^{\circ} \mathrm{C}$ until the time of analysis.

\subsection{Determinations}

\section{Proximate composition}

The proximate composition was determined every 8 days. Moisture was determined as described by Association of Association of Official Analytical Chemists (2010), Total nitrogen was determined by Kjeldahl method, considering the conversion factor of 6.25 for crude protein, according to Association of Official Analytical Chemists (2010); Total lipids were determined by the method of Bligh \& Dyer (1959); Ash content was determined according to the methodology of Association of Official Analytical Chemists (2010). Calorie values were estimated by the ATWATER coefficients (carbohydrates $=4.0 \mathrm{kcal} \mathrm{g}^{-1}$; lipids $=9.0 \mathrm{kcal} \mathrm{g}^{-1}$; and protein $=4.0 \mathrm{kcal} \mathrm{g}^{-1}$ (Merrill \& Watt, 1973).

\section{Minerals}

The determination of the minerals phosfhorus, calcium, magnesium, potassium, iron, manganese, zinc, and copper was performed by the method of nitroperchloric digestion according to methodology proposed by Malavolta et al. (1997). Results were expressed as mg $100 \mathrm{~g}^{-1}$ of fruit.

\section{Sugar profile}

The concentrations of sucrose, glucose, and fructose were determined by the method described by Metrohn (2015). Ion chromatography system 930 Compact IC Flex (Metrohm, Herisseau, Switzerland) was used, with column Metrosep Carb 1 (150/4.0) and sodium hydroxide as a mobile phase $\left(100 \mathrm{mmol} . \mathrm{L}^{-1}\right)$. Samples were diluted in pure water and filtered using $0.45 \mathrm{uM}$ filter. The running conditions were: injection volume $0.25 \mathrm{uL}$, flow rate $1.0 \mathrm{~mL} \cdot \mathrm{min}^{-1}$, oven temperature $35^{\circ} \mathrm{C}$, and run time 9 minutes. The results were compared with a calibration curve using standard solutions from 1 and $1000 \mathrm{mg} \cdot \mathrm{L}^{-1}$ (glucose and fructose) and 1 to $100 \mathrm{mg} \cdot \mathrm{L}^{-1}$ (sucrose).

\subsection{Statistical analysis}

The experiment was conducted in a completely randomized design (DIC), and the treatments were arranged in a factorial scheme composed by seven harvest points $(10,14,18,22,26$, 30 and 34 DAA), except for proximal composition, with four stages $(10,18,26$ and 34 DAA). Variables were submitted to polynomial regression analysis as a function of the harvest season. Sisvar software was used to fit the regression models to the $\mathrm{F}$ test at $5 \%$ probability to measure the importance of the model. All analyses were carried out in four replicates.

\section{Results and discussion}

The development stage of jabuticaba fruits was 34 days from flowering to harvest, represented by the growth, maturity, and ripening stages. According to Donadio (2000), jabuticaba fruit matures within three weeks after flowering. However, this period can vary according to the variety, climate, soil, temperature, among other factors, and the variety Pingo de Mel presented a higher development cycle.

During the 34 days of fruit development, significant differences $(p<0.05)$ were observed for all physicochemical determinations (Table 1). The initial moisture (10 DAA) of jabuticaba fruit was $74.50 \mathrm{~g} .100 \mathrm{~g}^{-1}$ of fruit, with an increase up to $18 \mathrm{DAA}$, and further decrease to 34 DAA, with moisture content of $80.87 \mathrm{~g} .100 \mathrm{~g}^{-1}$ of fruit (Figure 1). According to Awad (1993), this increase in moisture in the initial stages of fruit development is due to the expansion of cell wall after cell division, followed by influx of water into the vacuole. As a result, there is water accumulation into the cells during pulp development. In contrast, the lower moisture can be due to the transpiration, resulting in loss of turgor of the fruit.

Significant changes were observed for ash content of the fruits during growth and ripening (Figure 2). Until 18 DAA, the values remained stable, followed by a decrease at 26 DAA, with further increase up to 34 DAA. Minerals are essential for fruit metabolism, and mineral levels are dependent on several factors, such as soil fertility, climatic factors, and mainly the ability of the plant to absorb these elements from soil (Chitarra \& Chitarra, 2005). Thus, the differences in mineral levels of jabuticaba fruits can be due to climatic variations and availability of mineral elements in the soil during the life cycle of the fruit.

An increase in protein content was observed up to $18 \mathrm{DAA}$ with subsequent reduction to $34 \mathrm{DAA}$, corroborating the results obtained by Tlili et al. (2014), who studied Rhus tripartitum fruit grown in two locations and three maturity stages, and found similar protein behavior. According to Chitarra \& Chitarra (2005), the synthesis of nucleic acids and proteins is more pronounced in the early maturation stages, thus justifying the behavior of this macronutrient in jabuticaba fruits. In contrast, the protein reduction in the later stages may be due to its utilization in metabolism processes, including enzymatic activities (Silva, 2009).

Similar behavior was observed for the lipid content when compared to proteins (Figure 2). Silva et al. (2007) evaluated papayas at different maturity stages, and also observed a reduction of lipid content in the pulp and seeds. This fat reduction has been associated with the action of lipoxygenase, which contributes to a reduction of lipid components, since this enzyme has some activity during ripening and senescence of fruit (Ferrie et al., 1994; Hildebrand, 1989; Palyiath \& Droillard, 1992). Total carbohydrates were calculated by difference, and an opposite behavior was observed when compared to proteins and lipids, with a reduction up to $18 \mathrm{DAA}$, followed by an increase to full maturity (Figure 2). 
Table 1. Mean values and standard deviation of the content moisture (g.100 g of fruit), ash (dry basis - g. $100 \mathrm{~g}^{-1} \mathrm{of}$ fruit), potassium (mg.100 g-1 of fruit), phosphorus (mg.100 g of fruit), calcium (mg.100 g-1 of fruit), magnesium (mg.100 g ${ }^{-1}$ of fruit), copper (mg.100 g of fruit), iron (mg.100 g ${ }^{-1}$ of fruit), manganese (mg.100 g-1 of fruit), zinc (mg.100 g-1 of fruit), proteins (dry basis - g. $100 \mathrm{~g} \mathrm{~g}^{-1} \mathrm{of} \mathrm{fruit}^{-1}$ ), lipids (dry basis - g.100 g $\mathrm{g}^{-1}$ fruit), carbohydrates (dry basis - g.100 $\mathrm{g}^{-1}$ of fruit), glucose (g.100 g-1 of fruit), fructose (g.100 $\mathrm{g}^{-1}$ of fruit) e sucrose (g.100 g-1 of fruit) during the physiological development of jabuticaba variety Pingo de Mel harvested in the Fazenda \& Vinícula Jabuticabal, Nova Fatima-GO.

\begin{tabular}{|c|c|c|c|c|c|c|c|}
\hline \multirow{2}{*}{ Analyses } & \multicolumn{7}{|c|}{ Days after anthesis (DAA) } \\
\hline & 10 & 14 & 18 & 22 & 26 & 30 & 34 \\
\hline Moisture & $74.50 \pm 1.302$ & - & $87.66 \pm 0.122$ & - & $84.28 \pm 0.962$ & - & $80.87 \pm 0.789$ \\
\hline Ash & $3.21 \pm 0.147$ & - & $3.16 \pm 0.133$ & - & $2.80 \pm 0.226$ & - & $3.85 \pm 0.076$ \\
\hline Phosphorus & $283.49 \pm 0.001$ & $290.22 \pm 0.001$ & $250.51 \pm 0.002$ & $260.51 \pm 0.001$ & $193.42 \pm 0.001$ & $176.06 \pm 0.002$ & $153.38 \pm 0.001$ \\
\hline Calcium & $239.56 \pm 0.001$ & $253.12 \pm 0.001$ & $136.52 \pm 0.001$ & $165.78 \pm 0.001$ & $74.39 \pm 0.001$ & $115.20 \pm 0.002$ & $110.18 \pm 0.001$ \\
\hline Iron & $3.50 \pm 0.001$ & $2.19 \pm 0.002$ & $2.19 \pm 0.000$ & $1.81 \pm 0.002$ & $1.49 \pm 0.001$ & $1.03 \pm 0.002$ & $1.10 \pm 0.001$ \\
\hline Manganese & $2.85 \pm 0.001$ & $2.82 \pm 0.001$ & $1.96 \pm 0.001$ & $1.48 \pm 0.001$ & $0.95 \pm 0.001$ & $0.83 \pm 0.001$ & $0.87 \pm 0.001$ \\
\hline Zinc & $0.84 \pm 0.002$ & $0.74 \pm 0.003$ & $0.77 \pm 0.002$ & $0.68 \pm 0.002$ & $0.67 \pm 0.001$ & $0.65 \pm 0.001$ & $0.68 \pm 0.002$ \\
\hline Proteins & $26.04 \pm 0.011$ & - & $44.42 \pm 2.298$ & - & $27.53 \pm 3.231$ & - & $14.88 \pm 1.347$ \\
\hline Lipids & $6.53 \pm 0.264$ & - & $13.89 \pm 1.640$ & - & $8.74 \pm 0.098$ & - & $5.11 \pm 0.175$ \\
\hline
\end{tabular}

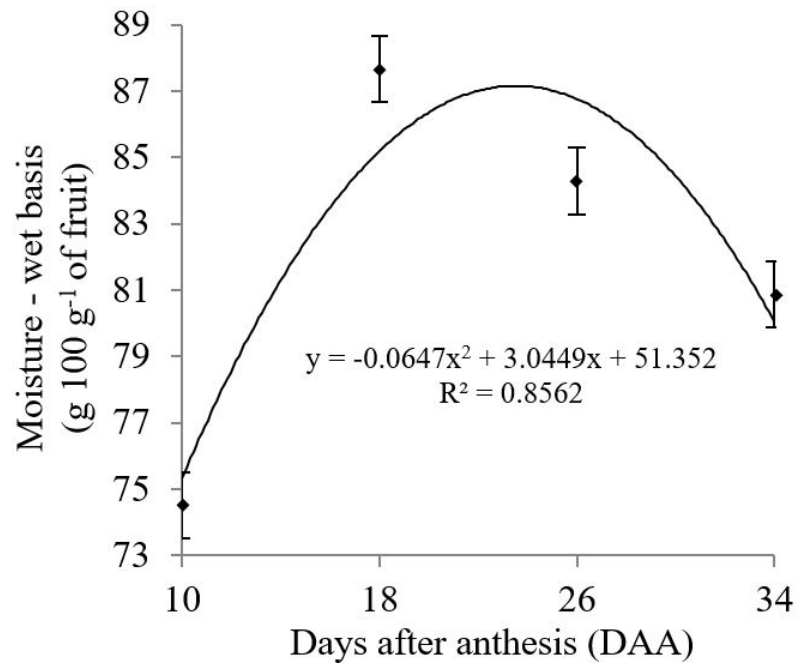

Figure 1. Mean values and standard deviation of the moisture content (wet basis) during development stage of jabuticaba variety Pingo de Mel, harvested in the Fazenda \& Vinícula Jabuticabal, Nova Fatima-GO.

The concentration of macro and micro minerals decreased during growth and ripening of the fruits, with the exception of potassium and copper, with a peak at $18 \mathrm{DAA}$, as shown in Figure 3. According to Galho et al. (2007), this reduction during ripening is due to dilution of these minerals during the development stages.

Potassium stood out among the macro minerals, with values greater than all other minerals throughout the life cycle, which can be explained by Vieira et al. (2010), who reported that potassium along with sucrose is the main component of osmotic phloem sap. Furthermore, potassium is an important regulator of neuromuscular activity, for example, fatigue, weakness, and cramps, and promotion of cell growth (Marques et al., 2010). Phosphorous was the second most abundant mineral in jabuticaba, followed by calcium and magnesium. Lower levels of these macro minerals were found in araca fruits by Galho et al. (2007), with values maximum the $250 \mathrm{mg} .100 \mathrm{~g}^{-1}$ of potassium, $150 \mathrm{mg}^{1} 100 \mathrm{~g}^{-1}$ of calcium, $30 \mathrm{mg} .100 \mathrm{~g} \mathrm{~g}^{-1}$ of magnesium and $20 \mathrm{mg} .100 \mathrm{~g}^{-1}$. Lima et al. (2011) studied the mineral composition of jabuticaba fruits and fractions of two different genotypes, and found that potassium, calcium, and magnesium were in higher concentrations in the fruit peel than in other parts.

Within the universe of trace minerals in jabuticaba fruits (Figure 3), the highest concentration was observed for copper, followed by iron, manganese, and zinc. According to Franco (2003), although copper is a trace element, it is essential in several metabolic functions with iron mobilization for hemoglobin synthesis, besides being a component of many enzymes, including cytochrome C-oxidase, superoxide dismutase, and monoamine oxidase.

Sugar composition is one of the most important parameters for the assessment of fruit quality, since it determines the consumption and the post-harvest storage conditions (Zhu et al., 2013). Sucrose, glucose, and fructose was detected by ion chromatograph in all samples (Figure 4), and fructose was found in higher concentrations, followed by glucose and sucrose, respectively, corroborating Lima et al. (2011) and Silva et al. (2017). Although sucrose is the most common transport sugar in plants, when reaching the non-photosynthetic tissues like fruits, it is degraded into hexoses through different metabolic pathways, aimed at regulation of gene expression and plant development (Ruan et al., 2010; Koch, 1996).

Maximum concentrations of reducing sugars (glucose and fructose) and sucrose were observed at 30 and 34 DAA. 


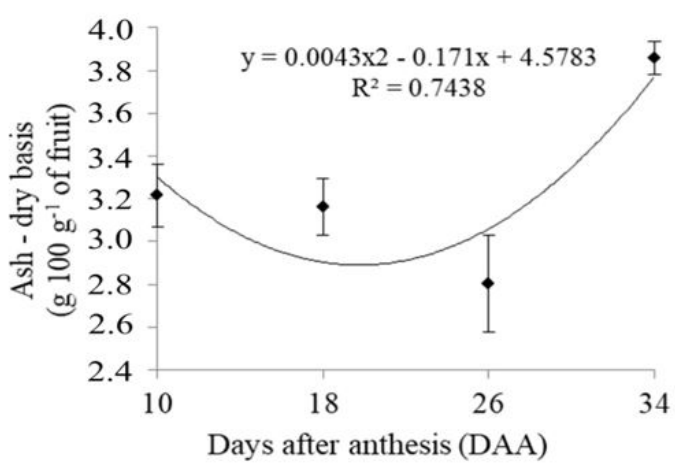

(a)

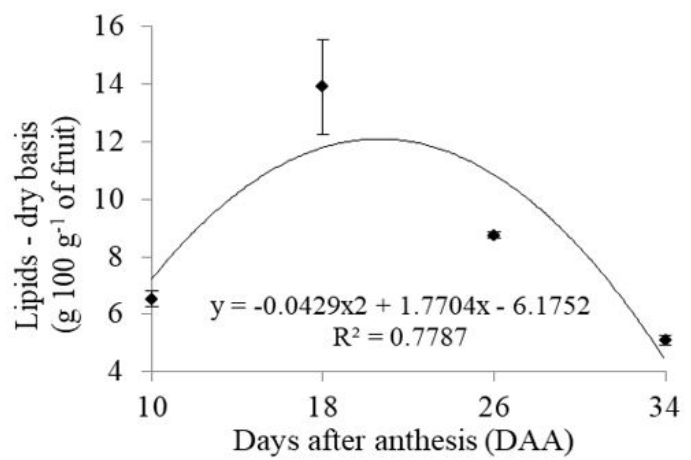

(c)

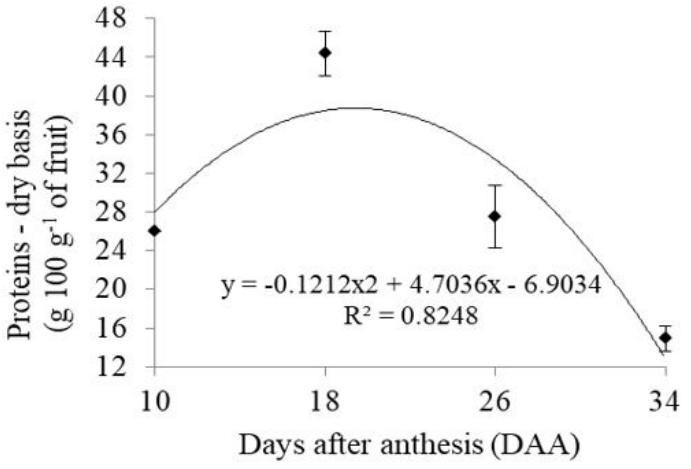

(b)

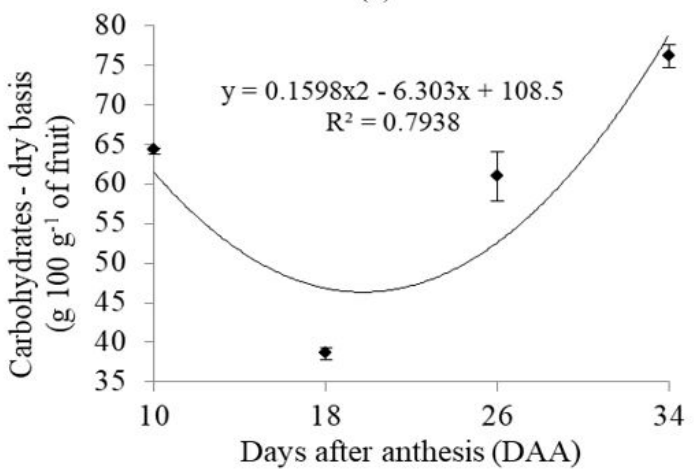

(d)

Figure 2. Mean values and standard deviation of ash (a), proteins (b), lipids (c), and carbohydrates (d) on a dry basis during the physiological development of jabuticaba variety Pingo de Mel harvested in the Fazenda \& Vinícula Jabuticabal, Nova Fatima-GO.

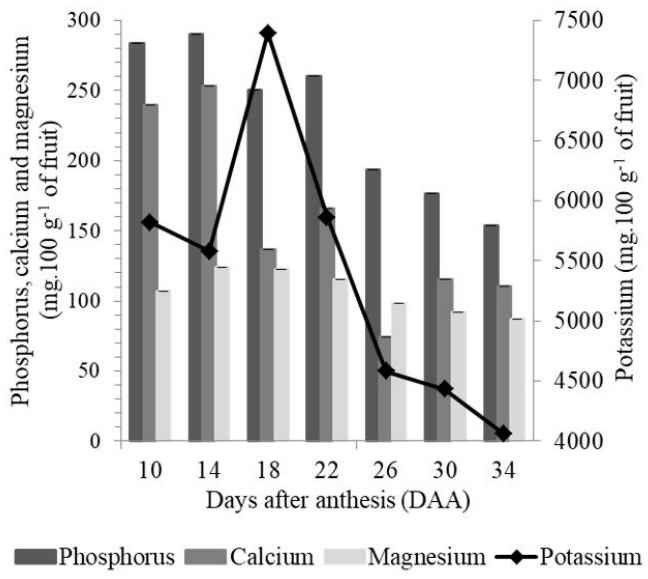

(a)

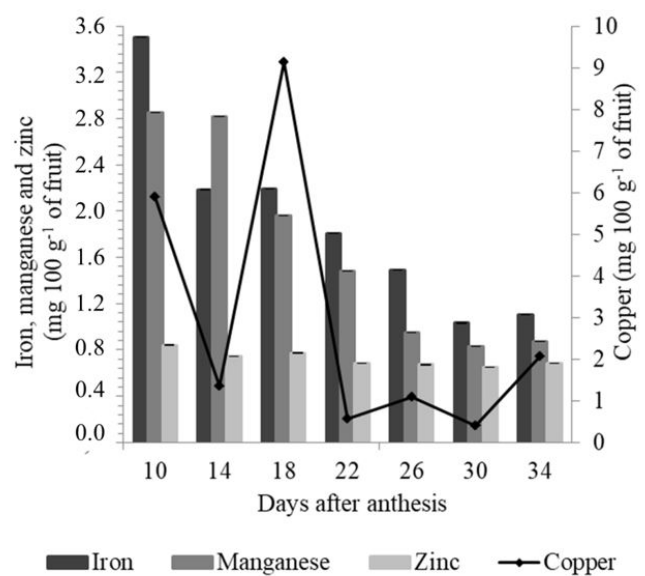

(b)

Figure 3. Mean values and standard deviation of micro (a) and macro minerals (b) during the physiological development of jabuticaba variety Pingo de Mel harvested in the Fazenda \& Vinícula Jabuticabal, Nova Fatima-GO.

Lima et al. (2011) studied two mature jabuticaba genotypes (Paulista and Sabara), and found similar values for glucose and sucrose. With respect to jabuticaba Paulista, glucose and fructose concentrations were $38.25 \pm 4.57 \mathrm{~g} .100 \mathrm{~g}^{-1}$ of fruit and $32.87 \pm 3.25 \mathrm{~g} .100 \mathrm{~g}^{-1}$ of fruit, respectively, while the genotype Sabará presented $32.96 \pm 2.68 \mathrm{~g} .100 \mathrm{~g}^{-1}$ of fruit and $26.40 \pm 0.60 \mathrm{~g} .100 \mathrm{~g}^{-1}$ of fruit for fructose and glucose, respectively. However sucrose levels were quite discrepant between genotypes, with values of $9.87 \pm 0.27{\mathrm{~g} .100 \mathrm{~g}^{-1} \text { of }}$ fruit and $11.69 \pm 0.21 \mathrm{~g} .100 \mathrm{~g}^{-1}$ of fruit for Paulista and Sabara, respectively, probably due to weather conditions and preparation of samples for analysis. 


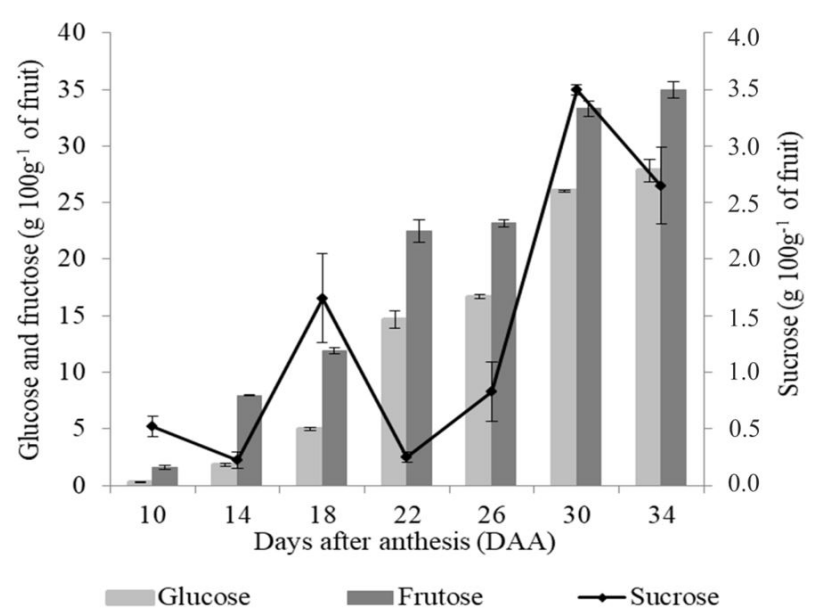

Figure 4. Mean values and standard deviation of glucose, fructose, and sucrose during the physiological development of jabuticaba variety Pingo de Mel harvested in the Fazenda \& Vinícula Jabuticabal, Nova Fatima-GO.

\section{Conclusion}

The jabuticaba fruits variety Pingo de Mel exhibited a decrease in moisture, proteins, lipids, and minerals during the physiological development, while an increase in sugar levels was observed up to $34 \mathrm{DAA}$. Whereas the sweet taste of fruit is a major factor for both consumption in natura and processing, we observed that jabuticaba fruits harvested 34 days after anthesis presented the best results.

\section{Acknowledgements}

The authors are grateful to FAPEG (Research Foundation of the State of Goías, Brazil) for the concession of a scholarship to Lismaíra Gonçalves Caixeta Garcia and to the Fazenda \& Vinícola Jabuticabal for donating the fruits used in the research. Clarissa Damiani is a PQ-CNPq Researcher.

\section{References}

Association of Official Analytical Chemists - AOAC. (2010). Official methods of analysis (18th ed., 3th Review). Washington: AOAC.

Awad, M. (1993). Fisiologia pós-colheita de frutos São Paulo: Nobel.

Bligh, E. G., \& Dyer, W. J. (1959). A rapid method of total lipid extraction and purification. Canadian Journal of Biochemistry and Physiology, 37(8), 911-917. http://dx.doi.org/10.1139/o59-099. PMid:13671378.

Boari Lima, A. J., Duarte Corrêa, A., Carvalho Alves, A. P., Patto Abreu, C. M., \& Dantas-Barros, A. M. (2008). Chemical characterization of the jabuticaba fruits (Myrciaria cauliflora Berg) and their fractions. Archivos Latinoamericanos de Nutricion, 58(4), 416-421. PMid:19368305.

Chitarra, M. I., \& Chitarra, A. B. (2005). Pós-colheita de frutos e hortaliças: fisiologia e manuseio (2nd ed). Lavras: UFLA.
Coombe, B. G. (1976). The development of fleshy fruits. Annual Review of Plant Physiology, 27(1), 507-528. http://dx.doi.org/10.1146/ annurev.pp.27.060176.001231.

Donadio, L. C. (2000). Jabuticaba (Myrciaria jaboticaba (Vell) Berg). Jaboticabal: FUNEP

Ferrie, B. J., Beaudoin, N., Burkhart, W., Bowsher, C. G., \& Rothstein, S. J. (1994). The cloning of two tomato lipoxygenases genes and their differential expression during fruit ripening. Plant Physiology, 106(1), 109-118. http://dx.doi.org/10.1104/pp.106.1.109. PMid:7972514.

Franco, G. (2003). Tabela de composição química dos alimentos (9th ed). São Paulo: Atheneu.

Galho, A. S., Lopes, N. F., Bacarin, M. A., \& Lima, M. G. S. (2007). Chemical composition and growth respiration in Psidium cattleyanum sabine fruits during the development cycle. Revista Brasileira de Fruticultura, 29(1), 61-66. http://dx.doi.org/10.1590/S0100-29452007000100014.

Hildebrand, D. F. (1989). Lypoxigenases. Physiologia Plantarum, 76(2), 249-253. http://dx.doi.org/10.1111/j.1399-3054.1989.tb05641.x.

Koch, K. E. (1996). Carbohydrate-modulated gene expression in plants. Annual Review of Plant Physiology and Plant Molecular Biology, 47(1), 509-540. http://dx.doi.org/10.1146/annurev.arplant.47.1.509. PMid:15012299.

Lima, A. J. B., Corrêa, A. D., Dantas-Barros, A. M., Nelson, D. L., \& Amorim, A. C. L. (2011). Sugars, organicacids, minerals and lipids in jabuticaba. Revista Brasileira de Fruticultura, 33(2), 540-550. http://dx.doi.org/10.1590/S0100-29452011000200026.

Malavolta, E., Vitti, G. C., \& Oliveira, S. A. (1997). Avaliação do estado nutricional das plantas: princípios e aplicações (2nd ed.). Piracicaba: POTAFOS.

Marques, A., Chicaybam, G., Araujo, M. T., Manhães, L. R. T., \& SabaaSrur, A. U. (2010). Mango rind and pulp (Mangifera indica L.) cv. Tommy Atkins centesimal composition and minerals contents. Revista Brasileira de Fruticultura, 32(4), 1206-1210. http://dx.doi. org/10.1590/S0100-29452010005000117.

Merrill, A. L., \& Watt, B. K. (1973). Energy value of foods: basis and derivation (Agriculture Handbook, 74). Washington: United States Department of Agriculture.

Metrohn. (2015). IC Application Note P-48: glucose, fructose and sucrose applying pulsed amprometric detection using the 930 Compact IC Flex. Thailand: Metrohm Siam. Retrieved from http://www.metrohm. co.th/news/20140605_metrohm_analysis_of_glucose_fruct

Palyiath, G., \& Droillard, M. J. (1992). The mechanisms of membrane deterioation and disassembly during senescence. Plant Physiology and Biochemistry, 30(6), 789-812.

Plagemann, I., Krings, I., Berger, R. G., \& Maróstica, M. R. Jr. (2012). Volatile constituents of jabuticaba (Myrciaria jaboticaba (Vell.) O. Berg) fruits. The Journal of Essential Oil Research, 24(1), 45-51. http://dx.doi.org/10.1080/10412905.2012.645651.

Ruan, Y.-L., Jin, Y., Yang, Y.-J., Li, G.-J., \& Boyer, J. S. (2010). Sugar input, metabolism, and signaling mediated by invertase: roles in development, yield potential, and response to drought and heat. Molecular Plant, 3(6), 942-955. http://dx.doi.org/10.1093/mp/ ssq044. PMid:20729475.

Silva, E. P. (2009). Caracterização do desenvolvimento de frutos do cerrado: marolo (Annona crassiflora, Mart) e gabiroba (Campomanesia pubescens) (Dissertação de mestrado). Universidade Federal de Lavras, Lavras. 
Silva, G. G., Diniz, R. G., \& Silva, M. E. (2007). Avaliação química do mamão papaia (Carica papaya L.) em diferentes estádios de maturação. Revista Capixaba de Ciência e Tecnologia, 3, 1-7.

Silva, M. M. M., Silva, E. P., Silva, F. A., Ogando, F. I. B., Aguiar, C. L., \& Damiani, C. (2017). Physiological development of cagaita (Eugenia dysenterica). Food Chemistry, 217, 74-80. http://dx.doi.org/10.1016/j. foodchem.2016.08.054. PMid:27664610.

Tlili, N., Tir, M., Benlajnef, H., Khemiri, S., Mejri, H., Rejeb, S., \& Khaldi, A. (2014). Variation in protein and oil content and fatty acid composition of Rhustripartitum fruits collected at different maturity stages in different locations. Industrial Crops and Products, 59, 197-201. http://dx.doi.org/10.1016/j.indcrop.2014.05.020.

Vieira, E. L., Souza, G. S., Santos, A. R., \& Silva, J. S. (2010). Manual de fisiologia vegetal. São Luis: EDUFMA.

Zhu, Z., Liu, R., Li, B., \& Tian, S. (2013). Characterisation of genes encoding key enzymes involved in sugar metabolism of apple fruit in controlled atmosphere storage. Food Chemistry, 141(4), 3323-3328. http://dx.doi.org/10.1016/j.foodchem.2013.06.025. PMid:23993488. 